\title{
Can Country Image Change after Likable Incident? The Case of Chile Miners' Rescue Operation and the Middle East Consumers
}

\author{
Saeb Farhan Al Ganideh \\ Department of Marketing, Al Zaytoonah University of Jordan \\ PO box 130, Amman 11733, Jordan \\ Tel: 962-6-429-1511Ｅ-mail: saebfarhan@yahoo.co.uk
}

Received: December 8, 2011

Accepted: December 24, 2011

Published: March 1, 2012

doi:10.5539/ibr.v5n3p100

URL: http://dx.doi.org/10.5539/ibr.v5n3p100

\begin{abstract}
Country image plays a key role in influencing consumers' perceptions towards products originating from foreign countries. Economic and commercial relations between countries in the Middle East region and South America have improved strongly in the last decade. However, there is a dearth of studies conducted in the Middle East countries regarding products sourced from South American countries. This study aims to explore how Chile miners' rescue operation has been perceived by Jordanians and how it has influenced the country image of Chile. The study examines the influence of demographic variables and openness to other cultures on the attitudes of Jordanian consumers towards Chile miners' rescue operation. A survey was conducted in the spring of 2011 to collect data from Jordanian consumers. Data were collected from 154 Jordanian customers. The results showed that Chile miners rescue operation has been admired most by Jordanian consumers who live in the capital of the country and by Jordanians who are more opened to other cultures.
\end{abstract}

Keywords: Country-of-image, Country-of-origin, Chile, Miners' rescue operation, Jordan

\section{Introduction}

The extraordinary technical and communication developments over the past decade have compelled firms to increasingly engage in global marketing activities (Chung, Pysarchik \& Hwang, 2009). Globalization has forced companies and organizations in developed countries to reengineer their activities to compete low cost products which originating from developing countries (Ryan, 2008). Moreover, it has motivated marketers from both developed and developing countries to find new markets for their products.

For over 5 decades Country-of-Origin ( $\mathrm{COO}$ ) can be considered the most studied topic in international business and marketing. $\mathrm{COO}$ refers to consumers' perception towards the products made in a particular country or region. $\mathrm{COO}$ concept has been developed based the idea that consumers have stereotypes concerning foreign countries which influence their evaluations of products originating from such countries (Giraldi \& Ikeda, 2009). Recently, the influence of $\mathrm{COO}$ information becomes less influential for consumers in a globalized world as it is not simple for them to consider the multiplicity of country information (manufacture, design, assembly and head office) (Chung et al., 2009; Tigli, Pirtini \& Erdem, 2010). In this context, it is important to indicate that consumers have become aware of current complex manufacturing processes, however, they do form perceptions of foreign products based on available information (Chandrasen, Cordon Bleu Dusit \& Paliwoda, 2009). Overall, findings in COO research are so strong that COO does affect global consumers (Giraldi \& Ikeda, 2009). Therefore, a number of countries employ $\mathrm{COO}$ effect to market and reinforce positive perceptions towards their products (Ryan, 2008; Tigli et al., 2010). This influence could be negative in some cases. COO could work to a product's disadvantage (Hoyer \& MacInnis, 2001). For example, consumers in developing countries were found to prefer products sourced from developed countries to products originating from developing countries (i.e Kaynak, Kara \& Nakip, 1995; Bhuian, 1997; Okechuku \& Onyemah, 1999; Kaynak \& Kara, 2002; Ryan, 2008; Al Ganideh, 2008). Based on the country's image, international marketers can accentuate $\mathrm{COO}$ information if a country's image is favorable and downplay $\mathrm{COO}$ information if its image is unfavorable (Ahmed et al, 2004). International business COO literature has ignored examining the impact of globalization on consumers' perceptions and attitudes (Suh \& Smith, 2008). Developing countries in general and particularly Arab countries have been ignored in most of international business research (Al Ganideh, 2010). Alternatively, international business literature has focused on developed countries and China and has paid less attention on emerging marketing in Latin America (Bianchi \& Garcia, 2007). Moreover, there is a great 
need in international business to explore the influence of demographic variables on consumers' preferences purchase decisions of foreign products (Khan \& Bamber, 2008). In their reviewing to COO international literature, Giraldi and Ikeda (2009) argued that demographic variables such as age and gender and socio-physiological variables such as openness to other cultures may influence the $\mathrm{COO}$ effect. World-mindedness refers "to interest in or knowledge about international affairs; factual and topical statements frequently serve as items in scales that measure international-mindedness" (Sampson \& Smith, 1957, p.99). Kosterman and Feshbash (1989) argued that internationalism refers to attitude towards other nations. Internationalism refers to emotional support for international sharing and welfare (Lee, Hong \& Lee, 2003).

\section{Literature Review}

Country image refers to the picture and the reputation that individuals attach to products of a specific country (Nagashima, 1970; Zhang, 1997; Ryan, 2008). Country images are shaped through consumers' knowledge of a particular country or their knowledge of products sourced from that country (Ryan, 2008; Chung et al., 2009). Consumers are influenced by a country image when they evaluate products sourced from that country (Giraldi \& Ikeda, 2009). They purchase products of a particular country as a result of feelings of affinity for that country (Oberecker \& Diamantopoulos, 2011). Overall, country image influences consumer purchase preferences of foreign products (Yamoah, 2005).

Individuals do employ information they know about a particular country to evaluate products sourced from that country without considering information regarding products' attributes (Zhang, 1997). Favorable perceptions towards a specific country results in favorable perceptions towards products sourced from that country (Paswan \& Sharma, 2004). Overall, a connection between a country's economic development and the superiority of its products was approved in $\mathrm{COO}$ literature. International business literature has concluded that consumers prefer products sourced from highly industrialized countries (Chandrasen et al., 2009). Products sourced from developed countries are perceived as being superior to products originating from developing countries. Consumers consider the country's economic development when evaluating products sourced from foreign (Schooler, 1971; Bilkey \& Nes, 1982; Han \& Terpstra, 1988; Zain \& Yasin, 1997).

The importance of the concept of country of image has increased recently with the rapid globalization of markets (Stock, 2009). Many countries have acknowledged the value of a country's positive image on marketing success of their products abroad (Ryan, 2008). A number of countries have built up a country specific image with particular products such as Switzerland and watches, Japan and electronics and Germany and automobiles (Tigli et al., 2010; Josiassen, 2011). Overall, international business researchers should give more attention to understanding of the nature of the phenomenon of country image (Auruskeviciene et al, 2010). The country image influences the global competition position of a country and its products (Zeng, Go \& Kolmer, 2011). Global companies with manufacturing outlets in different countries of the world should employ the concept of country of image to market their products more efficiently (Stock, 2009; Tigli et al., 2010).

The dramatic increase of the Internet, television satellite channels and other new communication tools into consumers' daily life has increased globalization of the world. Country image can be changed as result of media exposure (Chung \& Woo, 2011). Thus, exploring the role of media in shaping country image is important (Stock, 2009). Cable news network (CNN) has been the pioneer in establishing a 24-h news network with good global reach and the channel success in covering the first Gulf conflict stimulated other broadcasting organizations, such as BBC World Television, NBC and Sky (Gilboa, 2005). International broadcasting networks such as BBC World Television, CNN, Fox news, France 24 and CCTV have helped individuals to be more opened to different cultures. Moreover, in the Arab world Arab broadcasting networks such as Al-Jazeera and Al-Arabia since their establishments last decade have used to provide Arab viewers with more global news than their local television stations used to show. Al-Jazeera News channel has become a credible source for world news for the Arabs (Al-Jenaibi, 2010). It is clear that global world news channels and extensive media converge of major sport events have helped individuals all over the world to be more opened to global culture. Global television converge plays key role in shaping and changing national images around the world (Zeng et al., 2011). Individuals all around the world have become more educated and more opened to other cultures (Paswan \& Sharma, 2004). However, consumers do differ in terms of their interaction with foreign cultures (Sharma, Shimp \& Shin, 1995). Overall, extensive global media coverage of a particular event influences the image of the country in which the event is taking place (Chung $\&$ Woo, 2011).

Governments should give high concern to their countries' images and should follow changes related to such images with time or events (Tigli et al., 2010). For example, a positive change of country image may occur as a result of hosting global major sport events such as hosting the FIFA World Cup or the Olympics (Auruskeviciene et al., 
2010). In this context, Chung and Woo (2011) concluded that hosting major sport events can improve country image. The researchers indicated that China's hosting of the 2008 summer Olympics has significantly improved the country image, however, China's image improvement has not reflected on the image of it products. Alternatively, Auruskeviciene et al. (2010) explored the effects of the Torino 2006 Winter Olympics on the image of Italy amongst young consumers from Lithuania and found that country image of Italy has not improved among young Lithuanians. It is important to examine how global mega events can reflect the county image (Zeng et al., 2011).

\subsection{Chile Miners' Rescue Operation}

Chile has been ignored in international business literature despite the country is considered as one of largest exporters in the world of natural resources such as copper, timber, salmon, and fruit (Bianchi \& Garcia, 2007). However, the extensive media coverage of trapped miners' rescue operation offered the Chillan Government officials a great opportunity to improve the image of their country. The successful rescue operation of the Chilean miners who were trapped at a depth of more than 2,000 feet for more than 60 days was an operation of human ingenuity which made the whole world happy (New Oxford Review, 2010). Miners' rescue operation inspired the Chilean Government as well as Chilean marketers to promote a new image for the country. Rescue operation for Chilean miners has gained extreme global interest particularly with the extensive media coverage. World global and local news channels have interrupted their normal programs and focused on the happy end humanitarian rescue operation. Television coverage has made the dramatic operation watchable all over the World.

The Chilean Government has started soon after the successful rescue operation to build on the fascinating rescue operation to improve the country image all around the world. For example, the Chilean president visit to Jordan was one of Chile trials to maximize the benefits of its success in miners' rescue operation in the Arab region. King Abdullah II of Jordan and Chile's President Sebastián Piñera have stressed the importance of strengthening Jordanian-Chilean ties and increasing cooperation between the two countries particularly in the fields of economy and commerce (Jordan Times, 2011). Earlier, King Abdullah II has visited Chile in 2008 and made a speech at the National Congress of Chile Santiago, Chile. In his speech the king of Jordan called for partnership between Jordan and Chile especially the two countries share trade, diplomatic and cultural strong relationships (Jordan Times, 2008). Studying the image of Chile globally and addressing how consumers worldwide perceive Chile and its image is important (Bianchi \& Garcia, 2007). The current study examines the influence of the Chile miners' rescue operation on the image of Chile amongst Jordanian consumers. More specifically, it aims to examine the influence of demographic variables and openness to other cultures on the attitudes of Jordanian consumers towards Chilean miners' rescue operation.

\section{Methodology}

Data was collected from Jordanian consumers from Amman city, the capital in Jordan and from Irbid city, the capital of Irbid Governorate during the spring of 2011 in a six week period. A total of 154 usable questionnaires were collected from Jordanian consumers. The respondents were advised to provide demographic information regarding their gender, marital status, geographical location and age. Table 1 presents demographic characteristics for the pooled sample.

Insert Table 1 Here

To measure Jordanian consumers' openness to foreign cultures they were asked to answer two items borrowed from Ruyter, Birgelen, and Wetzels (1998) (I would like to have opportunities to meet people from different countries and I am open-minded towards foreigners and their habits). Unfortunately, due to the surprise nature of Chilean miners' rescue operation, the current study could not be able to measure the influence of the rescue operation of the trapped miners on Chile image before and after the incident. Chung and Woo (2011) measured the impact of the 2008 summer Olympics on country of image pre and post the games. Also, Auruskeviciene et al. (2010) explored the effects of the Torino 2006 Winter Olympics on the image of Italy among young Lithuanians before and after games. Generally, international business researchers did not agree on how a country image can be measured (Auruskeviciene et al., 2010). Recently, Lala, Allred, and Chakraborty (2009) developed a scale to measure country image. The developed scale main dimensions are related to economic conditions, conflict, political structure, vocational training, work culture, environment, and labour.

To measure the influence that miners' rescue operation might have on the country image of Chile among Jordanians five items were developed. The notion of the five developed items have been employed form Gripsrud and Nes (1996) and from Lala et al. (2009). Gripsrud and Nes (1996) developed a scale to measure people and societal country image. The scale has been used recently in international business literature (i.e Auruskeviciene et al., 2010). However, Lala et al.'s (2009) developed scale measures country image regarding to economic conditions, conflict, political structure, vocational training, work culture, environment, and labour. 
The five developed items were (Miners' rescue operation in Chile was fascinating; I have watched the rescue operation on T.V screen for long hours with extreme happiness; Miners' rescue operation showed that Chile is a technologically developed country; My knowledge about Chile has increased dramatically as a result of the rescue operation; Miners' rescue operation showed that the Chilean workers are very hard workers). Cronbach's alpha was used to assess the employed measures internal consistently. The results of Cronbach's alpha proved the reliability of the used measures. Both measures have exceeded the recommended minimum acceptable level of reliability for Cronbach's alpha which is 0.60 .

\section{Data Analysis and Concluding Remarks}

Table 2 presents frequency results which show that more than 40 per cent of Arab Jordanians do believe that Chilean miners' rescue operation was fascinating. Approximately, 55 per cent of Jordanians have spent long hours watching the operation gleefully. Roughly half of the Jordanians believed that Chilean miners' rescue operation has presented Chile as a technologically developed country and has showed that Chilean workers are hard workers. Knowledge about Chile has increased dramatically for more than 38 per cent of Jordanians as a result of tapped miners' rescue operation.

Insert Table 2 Here

To explore the influence of openness to foreign culture over and above the impact caused by demographic variables hierarchal regression was conducted. The hierarchical regression procedure was conducted in a way that demographic variables were entered as one block to provide a baseline model and then openness to foreign culture was entered separately as a second block.

Insert Table 3 Here

Table 3 shows that the first block (demographic variables) proved to statistically significant $(\mathrm{F}=2.651, \mathrm{df}=[4,140]$, $\mathrm{p} \leq$ 0.01). Demographic variables namely, age; gender, marital status and geographical location explained 7 per cent of the total variance in Jordanians' perceptions towards Chilean miners' rescue operation and its influence on the Chile image. The addition of openness to foreign cultures separately as a second block to the demographic variables (the first block) was also statistically significant $(\mathrm{F}=3.503, \mathrm{df}=[5,139], \mathrm{p} \leq 0.01)$. The addition of openness to foreign cultures brought 4.2 per cent increase to the model.

Insert Table 4 Here

Regarding the individual influence of each variable on Jordanians' perceptions towards Chilean miners' rescue operation the results showed that geographical location and openness to foreign cultures have statistical significant influences on Jordanians' perceptions towards the rescue operation (Table 4). On the other hand, Jordanians' perceptions towards Chilean miners' rescue operation did not vary based on their age, gender and marital status. Jordanians who do live in Amman city, the capital of Jordan have more positive views towards Chilean miners' rescue operation. Moreover, consumers who are more opened to other cultures showed more positive attitudes to the rescue operation and its influence on Chile's image than consumers who are less opened to other cultures.

The findings of this study have revealed a number of implications that could be valuable for Chilean and Jordanian marketing managers as well as for Chilean officials who attempt to target Arab consumers. Overall, the rescue operation unquestionably has created positive global publicity for Chile. The results of this study proved that consumers from Jordan do have positive perceptions towards Chile as a result of trapped miners' rescue operation. Chilean Government is strongly recommended to build on miners' rescue operation to improve the country global image. Moreover, Chilean marketers should employ the rescue operation within their advertising campaigns. For Chilean global marketers who are targeting the Jordanian market targeting consumes from Amman city is well suggested. It is important for Chilean global marketers to conduct marketing communications that focus on miners' rescue operation which might encourage Jordanians and Arabs to buy products originating from Chile. Local Jordanian manufacturers and marketers are well recommended to consider licensing arrangements and cooperation agreements with Chilean manufacturers to improve their reputation and their sales within Jordan and the Arab region. The results of the current study can be generalized on other Arab countries in the Middle East and North Africa.

\section{Research Limitations and Direction for Further Research}

The sample size can be considered as a limitation for the current study. Moreover, the fact that the data have been collected from only two main cities in Jordan is another limitation for this study. In terms of measuring Jordanians' perceptions towards Chile and its miners' rescue operation the current study has built on previous literature, however, international business literature is strongly recommended to develop scales to measure the influence of global events on countries' images. The current study has examined the influence of demographic variables namely, 
age, gender, marital status and geographical location on Jordanians' perception towards Chile and its famous miners' rescue operation, future research should examine other demographic variables such as educational level and income. Moreover, the impact of socio-psychological variables such as xenophobia and foreign travel should be addressed in future research.

\section{References}

Ahmed, Z., Johnson, J., Yang, X., Fatt, C., Teng, H., \& Boon, L. (2004). Does country of origin matter for low-involvement products? International Marketing Review, 21(1), 102-120. http://dx.doi.org/10.1108/02651330410522925

Al-Jenaibi, B. (2010). The competition between Al-Jazeera's Arab News diversity and US channels: content analysis of Iraq war. Canadian Social Science, 6(4), 81-96.

Al Ganideh, S. F. (2010). Consumer ethnocentrism in the Jordanian market: the impact of socio-psychological variables on consumer ethnocentric tendencies. Journal of Business and Retail Management Research, 5(1), 10-22.

Al Ganideh, S. F. (2008). An investigation into consumer animosity amongst young educated Jordanians. International Journal of Management Cases, 10(3), 638-650.

Auruskeviciene, V., Pundziene, A., Skudiene, V., Gripsrud, G., Nes, E. B., \& Olsson, U. H. (2010). Change of attitudes and country image after hosting major sport events. Engineering Economics, 21(1), 53-59.

Bhuian, S. (1997). Saudi consumers' attitudes towards European, US and Japanese products and marketing practices. European Journal of marketing, 31(7), 467-486. http://dx.doi.org/10.1108/03090569710176628

Bianchi, C. C., \& Garcia, R. A. (2007). Export marketing strategies of a developing country: an exploratory study of the main challenges and success factors for Chilean food exporters. Journal of Food Products Marketing, 13(3), 1-19. http://dx.doi.org/10.1300/J038v13n03_01

Bilkey, J., \& Nes, E. (1982). Country of origin effects on product evaluations. Journal of International Business Studies, 13, 89-99. http://dx.doi.org/10.1057/palgrave.jibs.8490539

Chandrasen, A., Cordon Bleu Dusit, L., \& Paliwoda, S. J. (2009). Country of assembly (COA) effect on perceived automobile quality: a Thai consumers' perspective. Journal of Marketing Management, 25(5-6), 483-499. http://dx.doi.org/10.1362/026725709X461812

Chung, W., \& Woo, C. W. (2011). The effects of hosting an international sport event on a host country: the 2008 Summer Olympic Games. International Journal of Sports Marketing and Sponsorship, 2011(July), 281-300.

Chung, J-E., Pysarchik, D. T., \& Hwang, S-J. (2009). Effects of country-of-manufacture and brand image on Korean consumers' purchase intention. Journal of Global Marketing, 22, 21-41. http://dx.doi.org/10.1080/08911760802511352

Gilboa, E. (2005). Global television news and foreign policy: debating the CNN effect. International Studies Perspectives, 6, 325-341. http://dx.doi.org/10.1111/j.1528-3577.2005.00211.x

Giraldi, J., \& Ikeda, A. A. (2009). An application of the personification approach in the country image study. Brazilian Business Review, 6(2), 132-146.

Gripsrud, G., \& Nes, E. B. (1996). Hosting the Olympics: a natural experiment of country image effects, In Beracs, J., Bauer, B., \& Simon, J. (Eds). Proceedings 25th EMAC Conference, May 14-17, 1996, Budapest, Hungary, 511-523.

Han, C. M., \& Terpstra, V. (1988). Country-of-origin effects for uni-national and bi-national products. Journal of International Business Studies, 19(summer), 235-255.

Hoyer, W., \& MacInnis, D. (2001). Consumer Behaviour. Boston Mass: Houghton Mifflin Company.

Jordan Times. (2008). Chile Sign Cooperation Agreements. (2008, October 12), Amman, Jordan, 1.

Jordan Times. (2011). Chile Talk Mercosur FTA. (2011, March 7), Amman, Jordan, 1.

Josiassen, A. (2011). Consumer disidentification and its effects on domestic product purchases: an empirical investigation in the Netherlands. Journal of Marketing, 75, 124 -140. http://dx.doi.org/10.1509/jmkg.75.2.124

Kaynak, E., Kara, A., \& Nakip, M. (1995). Life-styles, household decision-making ethnocentrism and country-of-origin perceptions of Azerbaijani consumers. In Kaynak, E., \& Eren, T. (Eds), Proceedings of the Fourth International Management Development Association Conference, July 13-15, 1995, Istanbul, Turkey, 356-368. 
Kaynak, E., \& Kara, A. (2002). Consumer perceptions of foreign products: an analysis of product-country images and ethnocentrism. European Journal of Marketing, 36(7/8), 928-949. http://dx.doi.org/10.1108/03090560210430881

Khan, H., \& Bamber, D. (2008). Country of origin effects, brand, and social status in an emerging market. Human Factors and Ergonomics in Manufacturing, 18(5), 580-588. http://dx.doi.org/10.1002/hfm.20126

Kosterman, R., \& Feshbach, S. (1989). Toward a measure of patriotic and nationalistic attitudes. Political Psychology, 10(2), 257-273. http://dx.doi.org/10.2307/3791647

Lala, V., Allred, A. T., \& Chakraborty, G. (2009). A multidimensional scale for measuring country image. Journal of International Consumer Marketing, 21, 51-66. http://dx.doi.org/10.1080/08961530802125407

Lee, W., Hong, J., \& Lee, S. (2003). Communicating with American consumers in the post 9/11 climate: an empirical investigation of consumer ethnocentrism in The United States. International Journal of Advertising, 22, 487-510.

Nagashima, A. (1970). A comparison of Japanese and US attitudes toward foreign products. Journal of Marketing, 34, 68-74. http://dx.doi.org/10.2307/1250298

New Oxford Review. (2010). What lies beneath? (2010, 12), 12-16.

Oberecker, E. M., \& Diamantopoulos, A. (2011). Consumers' emotional bonds with foreign countries: does consumer affinity affect behavioural intentions? Journal of International Marketing, 19(2), 45-72. http://dx.doi.org/10.1509/jimk.19.2.45

Ruyter, K. D., Birgelen, M. V., \& Wetzels, M. (1998). Consumer ethnocentrism in international services marketing. International Business Review, 7, 185-202. http://dx.doi.org/10.1016/S0969-5931(98)00005-5

Ryan, J. (2008). The Finnish country-of-origin effect: the quest to create a distinctive identity in a crowded and competitive international marketplace. Journal of Brand Management, 16, (1/2), 13-20. http://dx.doi.org/10.1057/bm.2008.15

Paswan, A., \& Sharma, S. (2004). Brand country of origin (COO), knowledge and COO image: investigation in an emerging franchise market. Journal of Product and Brand Management, 13(3), 144-155. http://dx.doi.org/10.1108/10610420410538041

Sampson, D., \& Smith, H. (1957). A scale to measure world-minded attitudes. The Journal of Social Psychology, 45, 99-106. http://dx.doi.org/10.1080/00224545.1957.9714290

Schooler, R. D. (1971). Bias phenomena attendant to the marketing of foreign goods in the U.S.. Journal of International Business Studies, 2(1), 71-81. http://dx.doi.org/10.1057/palgrave.jibs.8490732

Sharma, S. H., Shimp, T. A., \& Shin, J. (1995). Consumer ethnocentrism: a test of antecedents and moderators. Journal of Academy of Marketing Science, 23(1), 26-37. http://dx.doi.org/10.1177/0092070395231004

Stock, F. (2009). Identity, image and brand: a conceptual framework. Place Branding and Public Diplomacy, 5, 118-125. http://dx.doi.org/10.1057/pb.2009.2

Suh, T., \& Smith, K. H. (2008). Attitude toward globalization and country-of-origin evaluations: toward a dynamic theory. Journal of Global Marketing, 21(2), 127-139. http://dx.doi.org/10.1080/08911760802135202

Tigli, M., Pirtini, S., \& Erdem, C. E. (2010). The perceived country of origin images in Turkey. International Business and Economies Research Journal, 9(8), 127-133.

Yamoah, F. A. (2005). Role and impact of product-country image on rice marketing: a developing country perspective. The Journal of American Academy of Business, 7(2), 265-276.

Zain, O., \& Yasin, N. (1997). The importance of country-of-origin information and perceived product quality in Uzbekistan. International Journal of Retail and Distribution Management, 25(4), 38-145. http://dx.doi.org/10.1108/09590559710166313

Zeng, G., Go, F., \& Kolmer, C. (2011). The impact of international TV media coverage of the Beijing Olympics 2008 on China's media image formation: a media content analysis perspective. International Journal of Sports Marketing \& Sponsorship, 2011(July), 281-300.

Zhang, Y. (1997). Country-of-origin effect: the moderating function of individual difference in information processing. International Marketing Review, 14(4), 266-287. http://dx.doi.org/10.1108/02651339710173453 
Table 1. Sample Profile

\begin{tabular}{|c|c|c|}
\hline Variable & Group & Percentage (\%) \\
\hline \multirow{2}{*}{ Gender } & Male & 70.1 \\
\cline { 2 - 3 } & Female & 29.9 \\
\hline \multirow{2}{*}{ Marital Status } & Single & 72.7 \\
\cline { 2 - 3 } & Married & 26.6 \\
\hline \multirow{2}{*}{ Geographical Location } & Amman (Central part of Jordan) & 73.9 \\
\cline { 2 - 3 } & Irbid (North of Jordan) & 26.2 \\
\hline \multirow{3}{*}{ Age } & $18-25$ & 57.7 \\
\cline { 2 - 3 } & $26-36$ & 29.9 \\
\cline { 2 - 3 } & $37-47$ & 10.4 \\
\cline { 2 - 3 } & Over 48 & 1.9 \\
\hline
\end{tabular}

Table 2. Descriptive Statistics (the Image of Chile among Jordanians)

\begin{tabular}{|c|c|c|c|c|}
\hline & Item & Agree & Neither agree nor disagree & Disagree \\
\hline 1 & Miners' rescue operation in Chile was fascinating. & $\begin{array}{c}64 \\
41.8 \%\end{array}$ & $\begin{array}{c}39 \\
25.5 \%\end{array}$ & $\begin{array}{c}50 \\
32.7 \%\end{array}$ \\
\hline 2 & $\begin{array}{l}\text { I have watched the rescue operation on T.V screen for long } \\
\text { hours with extreme happiness. }\end{array}$ & $\begin{array}{c}84 \\
54.6 \% \\
\end{array}$ & $\begin{array}{c}46 \\
29.9 \% \\
\end{array}$ & $\begin{array}{c}22 \\
14.2 \% \\
\end{array}$ \\
\hline 3 & $\begin{array}{l}\text { Miners' rescue operation showed that Chile is a } \\
\text { technologically developed country. }\end{array}$ & $\begin{array}{c}70 \\
45.4 \%\end{array}$ & $\begin{array}{c}60 \\
39.0 \%\end{array}$ & $\begin{array}{c}22 \\
14.2 \%\end{array}$ \\
\hline 4 & $\begin{array}{l}\text { My knowledge about Chile has increased dramatically as a } \\
\text { result of the rescue operation. }\end{array}$ & $\begin{array}{c}59 \\
38.3 \% \\
\end{array}$ & $\begin{array}{c}50 \\
32.5 \% \\
\end{array}$ & $\begin{array}{c}41 \\
26.6 \% \\
\end{array}$ \\
\hline 5 & $\begin{array}{l}\text { Miners' rescue operation showed that the Chilean workers are } \\
\text { very hard workers. }\end{array}$ & $\begin{array}{c}59 \\
44.0 \%\end{array}$ & $\begin{array}{c}50 \\
33.1 \%\end{array}$ & $\begin{array}{c}41 \\
13.3 \%\end{array}$ \\
\hline
\end{tabular}

Table 3. ANOVA Results

\begin{tabular}{|c|c|c|c|c|c|c|}
\hline Model & & Sum of Squares & Degree of Freedom & Mean Square & F Value & Significant \\
\hline \multirow{4}{*}{1} & Regression & 262.344 & 4 & 65.586 & 2.651 & $0.036^{*}$ \\
\cline { 2 - 7 } & Residual & 3463.283 & 140 & 24.738 & & \\
\cline { 2 - 7 } & Total & 3725.628 & 144 & & & \\
\hline \multirow{3}{*}{2} & Regression & 416.950 & 5 & 23.390 & 3.503 & $0.005^{* *}$ \\
\cline { 2 - 8 } & Residual & 3308.678 & 139 & & & \\
\cline { 2 - 8 } & Total & 3725.628 & 144 & & & \\
\hline
\end{tabular}

${ }^{*} \mathrm{P} \leq 0.05,{ }^{* *} \mathrm{P} \leq 0.01$; Model 1 ( $\mathrm{R}=0.265$, $\mathrm{R}$ Square $\left.=0.07\right)$, Model 2 ( $\mathrm{R}=0.335 \mathrm{R}$ Square $\left.=0.112\right)$.

Predictors (1): (Constant), age, gender, marital status, geographical location.

Predictors (2): (Constant), age, gender, marital status, geographical location, openness to foreign cultures. Dependent variable (Chile's country image).

Table 4. Regression Results

\begin{tabular}{|c|c|c|c|c|c|c|}
\hline Model & & \multicolumn{2}{|c|}{ Unstandardised Coefficients } & Standardised Coefficients & $\mathrm{t}$ & Significant \\
\hline & & $\mathrm{B}$ & Std. Error & Beta & & \\
\hline 2 & (Constant) & 8.456 & 3.258 & & 2.596 & $.010^{* *}$ \\
\hline & Age & $-.499-$ & .655 & $-.072-$ & $-.762-$ & .447 \\
\hline & Gender & $-1.324-$ & .902 & $-.121-$ & $-1.468-$ & .144 \\
\hline & Marital status & 1.038 & 1.127 & .096 & .921 & .359 \\
\hline & Geographical location & 2.562 & 1.040 & .224 & 2.463 & $.015^{*}$ \\
\hline & Openness to foreign cultures & .496 & .195 & .211 & 2.549 & $.012^{*}$ \\
\hline
\end{tabular}

${ }^{*} \mathrm{P} \leq 0.05,{ }^{* *} \mathrm{P} \leq 0.01$. 